\title{
PENGARUH PEMBERIAN TEPUNG BAWANG PUTIH (Allium sativum L) TERHADAP PERFORMANS PRODUKSI AYAM PEDAGING
}

\section{EFFECT OF GARLIC POWDER (Allium sativum L) ADDITION ON BROILER PRODUCTION PERFORMANCE}

\author{
Estepanus.L.S.Tumbal \\ Program Studi Peternakan Fakultas Pertanian dan Peternakan, Universitas Satya Wiyata \\ Mandala Nabire \\ Jl. Sutamsu SH, Kalibobo-Nabire \\ Penulis korespondensi email: elstumbal@gmail.com
}

\begin{tabular}{|l|l}
\hline Diterima : 28 Desember 2017 & Disetujui : 12 Januari 2018 \\
\hline
\end{tabular}

\section{Intisari}

Penelitian ini bertujuan untuk mengetahui efek pemberian tepung bawang putih (Allium sativum L) terhadap perfomans produksi ayam pedaging. Penelitian ini dilaksanakan selama 4 minggu menggunakan Rancangan Acak Lengkap dengan 4 perlakuan dan masingmasing perlakuan diulang $3 \mathrm{kali}$, dengan jumlah ayam setiap satuan percobaan sebanyak 3 ekor. Perlakuan yang diberikan adalah berbagai taraf pemberian tepung bawang putih (komersial) yang dilarutkan dalam air minum, yakni P0 (tanpa pemberian tepung bawang putih), P1 (dengan tepung putih 0,5\% atau $5 \mathrm{gr} /$ liter), P2 (dengan tepung bawang putih 1,0 $\%$ atau $10 \mathrm{gr} /$ liter) dan P3 (dengan tepung bawang putih 1,5\% atau $15 \mathrm{gr} /$ liter). Pemberian perlakuan dimulai pada saat ayam umur 1 minggu sampai umur 4 minggu, dengan interval waktu pemberian 2 hari sekali. Variabel yang diamati meliputi konsumsi ransum, pertambahan bobot badan dan konversi ransum. Hasil penelitian menunjukan bahwa pemberian tepung bawang putih tidak memberikan efek nyata $(\mathrm{P}>0,05)$ terhadap performans produksi baik terhadap konsumsi ransum, pertambahan bobot badan maupun konversi ransum. Secara numeric konsumsi ransum maupun konversi ransum menurun seiring meningkatnya taraf pemberian tepung bawang putih, sedangkan pertambahan bobot badan ayam tertinggi pada kelompok ayam yang diberi perlakuan P1, dan terendah pada kelompok ayam yang diberi perlakuan P3.

Kata kunci : ayam pedaging, tepung bawang putih, performans produksi.

\section{Abstract}

This study aims to determine the effect of addition garlic powder (Allium sativum L) on broiler production performance. This study was conducted for 4 weeks using Completely Randomized Design with 4 treatments, and each treatment was repeated 3 times, with the number of chickens per unit trial of 3 chicken. The treatments were various levels of garlic powder (commercial) dissolved in drinking water, P0 (without garlic powder), P1 (with $0.5 \%$ white flour or $5 \mathrm{gr} /$ liter), P2 (with garlic powder $1.0 \%$ or $10 \mathrm{gr} /$ liter), and P3 (with garlic powder $1.5 \%$ or $15 \mathrm{gr} /$ liter). Treatment begins at the time of chicken age 1 week until age 4 weeks, with the interval time of 2 days. Variable observed included dietary intake, weight gain, and the conversion of ransum. The results showed that giving garlic powder did not give a significantly effect $(\mathrm{P}>0,05)$ to production performance either to ransum consumption, body weight gain and ransum conversion. The numerical consumption of ransum, and ransum conversion decreased with increasing of garlic starch level, while the highest chicken body weight increased in P1 treated group and the lowest in P3 treated group.

Keywords: broiler, garlic powder, production performance 


\section{PENDAHULUAN}

\section{Latar Belakang.}

Salah satu cara untuk meningatkan penampilan produksi ternak unggas adalah menambahkan feed aditif dalam pakan. Feed aditif adalah bahan yang ditambahkan dalam jumlah sedikit untuk memacu pertumbuhan dan meningatkan efisiensi pakan serta mengurangi mikrooganisme pengganggu atau meningkatkan populasi mikroba yang menguntungkan dalam saluran pencernaan ayam (Tarmudji, 2004). Salah satu feed aditif digunakan adalah bawang putih (Allium sativum).

\section{Penggunaan bawang putih} sebagai bahan pengobatan berbagai penyakit sudah lama diketahui. Bawang putih memiliki kandungan senyawa aktif yang terbukti mampu menggantikan fungsi dari antibiotik sintetik didalam tubuh ayam. Beberapa senyawa aktif yang terkandung didalam umbi bawang putih adalah allicin, selenium dan metilatil trisulfida. Ketiga senyawa aktif ini mampu membantu terjadinya proses metabolisme di dalam tubuh ayam yang jauh lebih baik. Adanya beberapa kandungan senyawa aktif ini membuat bawang putih berpotensial untuk digunakan sebagai feed additive. Selain itu terdapat kandungan kimia yang berfungsi untuk obat pada bawang putih adalah sativine yaitu suatu senyawa kimia yang mempunyai daya mempercepat pertumbuhan sel dan pertumbuhan jaringan dan dapat merangsang susunan syaraf, allicin adalah senyawa yang berkhasiat sebagai antibiotika, siniatrin, saponin, nicotinic acid yang bersifat hipotensif, diallydisulfide sebagai anti cacing, vitamin A, B, C, dan D serta fosfor (Tampubolon, 1981). Namun penggunaan bawang putih sebagai obat memeliki keterbatasan selain karena aromanya yang sangat tajam, rasanya yang tidak enak (langu dan pedis), senyawa yang ada dalam bawang putih juga bersifat volatil yaitu mudah menguap dan hilang pada saat prosessing, baik karena proses pemanasan, penghancuran maupun oksidasi dengan lingkungan. Untuk mengatasi keterbatasan tersebut perlu dilakukan penanganan agar khasiat bawang putih tetap terjaga dan efisien dalam pemanfaatannya, salah satunya dengan cara dikeringkan dan dibuat tepung.

Berkaitan dengan banyaknya manfaat farmakologis pada bawang putih, yang berkhasiat mengobati berbagai penyakit, diharapkan pemberian bawang dapat meningkatkan derajat kesehatan ayam. Berdasarkan pertimbangan tersebut 
dilakukan penelitian tentang efek pemberian bawang putih terhadap performans produksi ayam pedaging.

\section{Rumusan Masalah}

Sebagaimana uraian latar belakang di atas maka rumusan masalah yang diajukan dalam penelitian ini adalah apakah pemberian bawang putih dalam bentuk tepung yang dilarutkan dalam air minum dapat memberikan efek terhadap performans produksi ayam pedaging.

\section{Tujuan Penelitian}

Penelitian ini bertujuan untuk mengetahui efek pemberian tepung bawang putih yang dilarutkan dalam air minum terhadap performans produksi ayam pedaging.

\section{Kegunaan Penelitian}

Hasil Penelitian ini diharapkan dapat menjadi informasi ilmiah tentang efek pemberian tepung bawang putih yang dilarutkan dalam air minum terhadap performas produksi ayam pedaging.

\section{Hipotesis}

Pemberian tepung bawang putih yang dilarutkan dalam air minum mempunyai efek meningkatkan kinerja produksi ayam pedaging.

\section{METODE PENELITIAN}

\section{Lokasi dan Waktu Penelitian}

Penelitian ini dilaksanakan selama 28 hari (4 minggu), mulai tanggal 10 Juli sampai dengan tanggal 08 Agustus 2016 di kandang peternakan milik Bapak Gunawan yang berlokasi di Kota Baru, Karang Mulia, Nabire.

\section{Alat dan Bahan}

Alat yang digunakan dalam penelitian ini adalah sebagai berikut :

$\checkmark$ Petak kandang ukuran $60 \times 60 \mathrm{~cm}$ sebanyak 12 petak

Wadah tempat pakan ayam kapasitas 2 kg sebanyak 12 buah $\checkmark$ Wadah tempat minum ukuran 1 liter sebanyak 12 buah

$\checkmark$ Timbangan duduk kapasitas $5 \mathrm{~kg} \quad 1$ buah

Lampu pijar 10 watt sebanyak 12 buah Litter kandang berbahan ampas serutan kayu secukupnya

Bahan yang digunakan dalam penelitian ini adalah :

$\checkmark$ DOC Ayam pedaging sebanyak 36 ekor

$\checkmark$ Tepung bawang putih kemasan (komersial) secukupnya

$\checkmark$ Ransum komersil merk Charoen Phokphan jenis bravo I (511) dan 
bravo II (512) masing - masing sebanyak 2 Zak $(1 \mathrm{zak}=50 \mathrm{~kg})$

$\checkmark$ Vitachick kemasan 500 gram 1 bungkus

$\checkmark$ Antiseptik kemasan 50 cc sebanyak 1 botol

Air minum sesuai kebutuhan

\section{Metode dan Rancangan Percobaan}

Penelitian ini dilaksanaan secara eksperimen dengan menggunakan rancangan acak lengkap (RAL). Perlakuan yang diterapkan pada ayam pedaging ini adalah pemberian tepung bawang putih yang dilarutkan dalam air minum dengan taraf yang berbeda dengan interval pemberian 2 hari sekali. Pemberian perlakuan dimulai pada hari ke 8 atau ayam berumur 7 hari dan diberikan selama 21 hari (sampai ayam berumur 28 hari). Adapun dosis masing - masing perlakuan adalah sebagai berikut :

$\mathrm{P} 0$ = Tanpa pemberian tepung bawang putih sebagai kontrol.

$\mathrm{P} 1=$ Pemberian tepung bawang putih $0,5 \%$ atau 5 gram/ liter air minum

$\mathrm{P} 2=$ Pemberian tepung bawang putih $1,0 \%$ atau 10 gram/ liter air minum

$\mathrm{P} 3=$ Pemberian tepung bawang putih $1,5 \%$ atau 15 gram/ liter air minum

Setiap perlakuan diulang tiga

(3) kali, sehingga terdapat dua belas (12) satuan percobaan, dan setiap satuan percobaan terdiri dari tiga (3) ekor ayam sehingga jumlah keseluruhan ayam yang digunakan dalam penelitian ini sebanyak 36 ekor.

$\begin{array}{lrr} & \text { Model matematik yang } \\ \text { digunakan dalam penelitian ini } & \\ \text { sebagaimana dirumuskan Steel dan Torrie }\end{array}$ (1989) adalah sebagai berikut :

$$
Y_{i j}=\mu+\sigma_{i}+\varepsilon_{i j}
$$

dimana :

$Y_{i j}=$ Pengaruh perlakuan ke $\mathrm{i}$ dan ulangan ke $\mathrm{j}$

$\mu=$ Nilai tengah umum

$\sigma_{\mathrm{i}}=$ Pengaruh perlakuan ke $\mathrm{i}, \mathrm{i}=1,2,3$, 4

$\varepsilon_{\mathrm{ij}}=$ Galat percobaaan dari perlakuan kei pada ulangan ke-j

\section{Pelaksanaan Penelitian}

Pelaksanaan penelitian terdiri dari 2 tahapan sebagai berikut :

Tahap pemeliharaan tanpa perlakuan

Pemeliharaan ini dimaksudkan untuk masa adaptasi ayam selama 7 hari (1 minggu). Pada hari pertama saat DOC baru datang (pagi hari), diberikan air minum larutan gula merah untuk mengurangi stress dan mengembalikan tenaga akibat perjalanan jauh menuju Nabire. Sedangkan pada sore harinya diberikan vitamin (vitachik) yang dilarutan pada air minumnya. Selanjutnya pada hari kedua sampai dengan hari ke tujuh 
ayam diberikan vitamin dengan interval 2 hari sekali.

Jenis pakan yang diberikan selama 1 minggu pertama ini adalah Bravo I (511 B) produksi PT. Charound Phokphan, dengan jumlah sesuai kebutuhan.

Tahap pemeliharaan dengan perlakuan

Tahap ini merupakan tahapan penelitian ini dimana terhadap sampel ayam penelitian diberikan perlakuan pemberian tepung bawang putih, dimulai pada awal minggu ke 2 ketika ayam berumur 7 hari (pada hari ke 8 pemeliharaan) dilaksanakan selama 3 minggu (minggu $2-4$ ), hal ini menyesuaikan dengan masa panen oleh pemilik peternakan yakni dipanen umur 4 minggu (28 hari). Secara berselang dengan interval 2 hari sekali ayam diberikan perlakuan tepung bawang putih yang dilarutkan pada air minum.

Jenis pakan yang diberikan selama tahap penelitian terdiri dari 2 jenis pakan yaitu Bravo I (511 B) diberikan sampai ayam berumur 3 minggu (21 hari), kemudian pada awal sampai akhir minggu ke 4 ( umur 22 sampai dipanen umur 28 hari) diberikan pakan Bravo II (512 B) produksi PT. Charound Phokphan, dengan jumlah sesuai kebutuhan.

Variabel Pengamatan
Vareabel yang diamati dalam penelitian ini adalah performan produksi yang meliputi :

Konsumsi Ransum

Konsumsi ransum yang diamati adalah konsumsi komulatif selama penelitian untuk setiap ekor ayam, dihitung dengan cara menimbang jumlah ransum yang disediakan dikurangi dengan ransum tersisa selama penelitian.

Konsumsi ransum dapat dihitung menggunakan rumus :

$\mathrm{KR}($ gram/ekor $)=\mathrm{JRB}-\mathrm{JRS}$

dimana :

$\mathrm{KR}=$ Jumlah ransum yang dikonsumsi

$\mathrm{JRB}=$ Jumlah ransum yang diberikan ( gram)

$\mathrm{JRS}=$ Jumlah ransum yang tersisa (gram)

Pertambahan Bobot Badan

Pertambahan bobot badan yang diamati adalah pertambahan bobot badan komulatif selama penelitian yang diperoleh dari selasih hasil penimbangan bobot badan akhir dan bobot badan awal penelitian. Pertambahan bobot badan ayam dapat dihitung dengan rumus :

$\mathrm{PBB}=\mathrm{BBt}-\mathrm{BBo}$

Dimana :

PBB $=$ Pertambahan Bobot Badan (gram/ ekor)

$\mathrm{BBt}=$ Bobot badan akhir $($ gram/ekor $)$

BBo $=$ Bobot badan awal (gram/ekor)

Konversi Ransum 
Konversi ransum merupakan perbandingan antara jumlah konsumsi ransum dengan $\mathrm{PBB}$.

Konversi ransum $=\frac{\text { Konsumsi }(\text { gram })}{\operatorname{PBB}(\text { gram })}$

\section{Analisa Data}

Data yang diperoleh dianalisis dengan analisis sidik ragam (Anova) dan apabila terdapat pengaruh yang nyata dari perlakuan maka akan dilanjutkan dengan uji Duncan Multiple Range Test (DMRT).

\section{HASIL DAN PEMBAHASAN}

\section{Konsumsi Ransum}

Rataan konsumsi ransum komulatif ayam pada penelitian disampaikan pada tabel 3 sebagai berikut :

Tabel 3. Konsumsi Ransum Komulatif Ayam Penelitian (gram/ekor)

\begin{tabular}{|c|c|c|c|c|c|}
\hline \multirow{2}{*}{ PERLAKUAN } & \multicolumn{3}{|c|}{ ULANGAN } & \multirow{2}{*}{ TOTAL } & \multirow{2}{*}{ RATAAN } \\
\hline & 1 & 2 & 3 & & \\
\hline P0 & 1.525 & 1.547 & 1.425 & 4.497 & 1.499 \\
\hline $\mathrm{P} 1$ & 1.353 & 1.556 & 1.582 & 4.491 & 1.497 \\
\hline $\mathrm{P} 2$ & 1.453 & 1.541 & 1.303 & 4.297 & 1.432 \\
\hline P3 & 1.316 & 1.391 & 1.543 & 4.251 & 1.417 \\
\hline
\end{tabular}

Sumber : Data primer diolah, 2016

Hasil analisis ragam (lampiran 4.1) menunjukkan bahwa pemberian perlakuan minum tidak berpengaruh nyata $(\mathrm{P}>$ 0.05) terhadap konsumsi ransum ayam pedaging, artinya pemberian tepung bawang putih yang dilarutkan dalam air tidak memberikan efek nyata terhadap peningkatan konsumsi pakan. Sutama dan Lindawati (2005) melaporkan, ayam petelur yang diberi suplementasi bawang putih sebesar 2-6 \% dalam ransumnya tidak memberikan pengaruh terhadap konsumsi ransum dan produksi telur yang dihasilkan. Namun demikian dari tabel 4 terlihat bahwa rataan konsumsi ransum komulatif semakin menurun seiring dengan meningkatnya taraf pemberian tepung bawang putih. Dibandingkan dengan hasil penelitian Zulbardi dan Bintang (2007) pemberian tepung bawang putih sebanyak 0,02\% mampu merangsang pertambahan bobot badan ayam broiler lebih cepat, pencapaian konversi pakan sebesar 1,81 dan diikuti dengan penurunan jumlah konsumsi pakan oleh ayam broiler.

Ilustrasi mengenai rataan konsumsi ransum komulatif ayam penelitian untuk masing-masing perlakuan dapat dilihat pada gambar 1 sebagai berikut : 


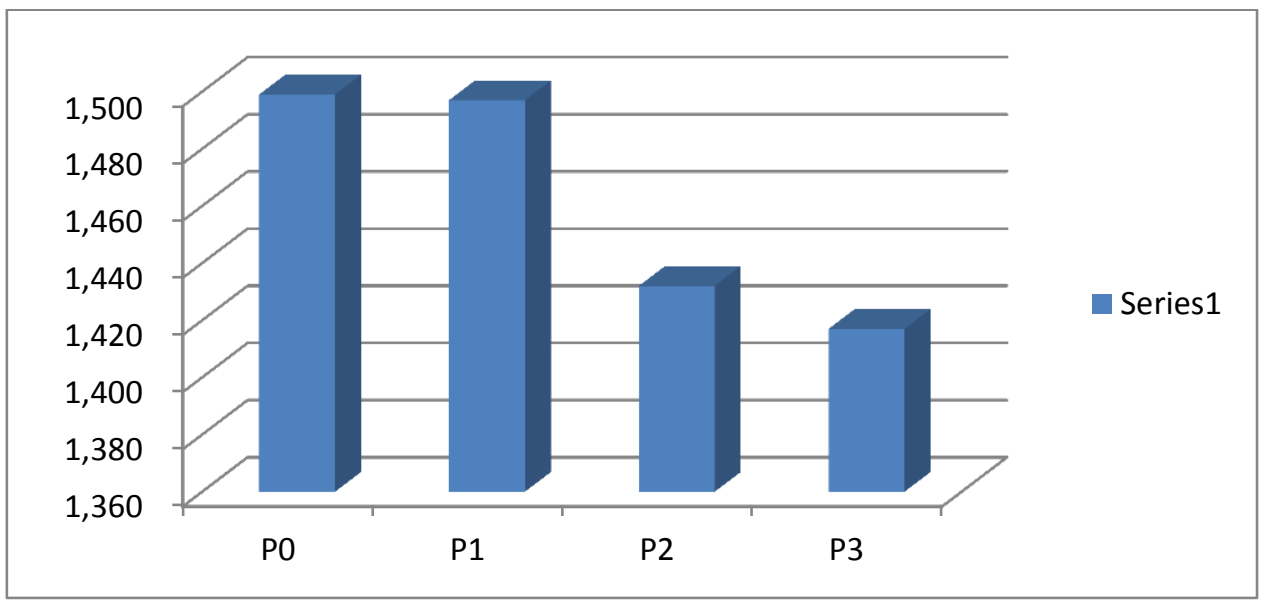

Gambar 1. Diagram Konsumsi Ransum Komulatif Ayam Penelitian

\section{Pertambahan Bobot Badan}

Hasil penelitian diperoleh bahwa pertambahan bobot badan (PBB) ayam sebagaimana terlihat pada Tabel 4 sebagai berikut:

Tabel 4. Pertambahan Bobot Badan Komulatif Ayam Penelitian (gram/ekor)

\begin{tabular}{cccccc}
\hline & \multicolumn{3}{c}{ ULANGAN } & TOTAL & RATAAN \\
\cline { 2 - 4 } & 1 & 2 & 3 & & \\
\hline P0 & 980 & 975 & 989 & 2.944 & 981 \\
P1 & 987 & 982 & 982 & 2.951 & 984 \\
P2 & 977 & 982 & 977 & 2.936 & 979 \\
P3 & 972 & 981 & 970 & 2.923 & 974 \\
\hline
\end{tabular}

Sumber : Data primer diolah, 2016

Berdasarkan hasil analisis ragam (lampiran 4.2) menunjukkan bahwa pemberian perlakuan tidak berpengaruh nyata $(\mathrm{P}>0,05)$ terhadap pertambahan bobot badan komulatif (PBB) ayam penelitian, artinya pemberian tepung bawang putih yang dilarutkan dalam air minum tidak memberikan efek nyata terhadap peningkatan pertambahan bobot badan. Namun demikian berdasarkan tabel 6 diatas rataan pertambahan bobot badan ayam tertinggi pada perlakuan P1 yaitu pada taraf pemberian tepung bawang putih $5 \mathrm{gr} /$ liter atau $0,05 \%$, namun menurun pada $\mathrm{P} 2$ dan $\mathrm{P} 3$ seiring dengan meningkatnya taraf. Hal ini dimungkinkan karena meningkatnya pemberian tepung bawang putih pada P2 dan P3 yaitu dengan taraf 10 dan 15 gr/liter dalam air minum justru menimbulkan suasana mulut (ayam) yang tidak enak akibat rasa pedis dan langu yang terkandung dalam bawang putih, akibatnya konsumsi ransum menjadi menurun dan pertambahan bobot badan juga menurun. Apabila dibandingkan 
dengan hasil penelitian Zulbardi dan Bintang (2007) sebagaimana disampaikan di atas bahwa mepemberian tepung bawang putih sebanyak 0,02 \% mampu merangsang pertambahan bobot badan ayam broiler lebih cepat. Sedangkan untuk ayam petelur, menurut Maryam et al (2003), pemberian ektrak bawang putih sebanyak $4 \%$ pada ransum ayam petelur yang diinfeksi aflaktosin $0,4 \mathrm{mg} \mathrm{AFB}_{1} / \mathrm{kg}$
BH dapat meningkatkan bobot badan dan produksi telur serta dapat mengurangi kadar residu aflaktosin pada telur yang dihasilkan.

$$
\text { Ilustrasi mengenai rataan }
$$
pertambahan bobot badan komulatif ayam penelitian untuk msing-masing perlakuan dapat dilihat pada gambar 2 sebagai berikut

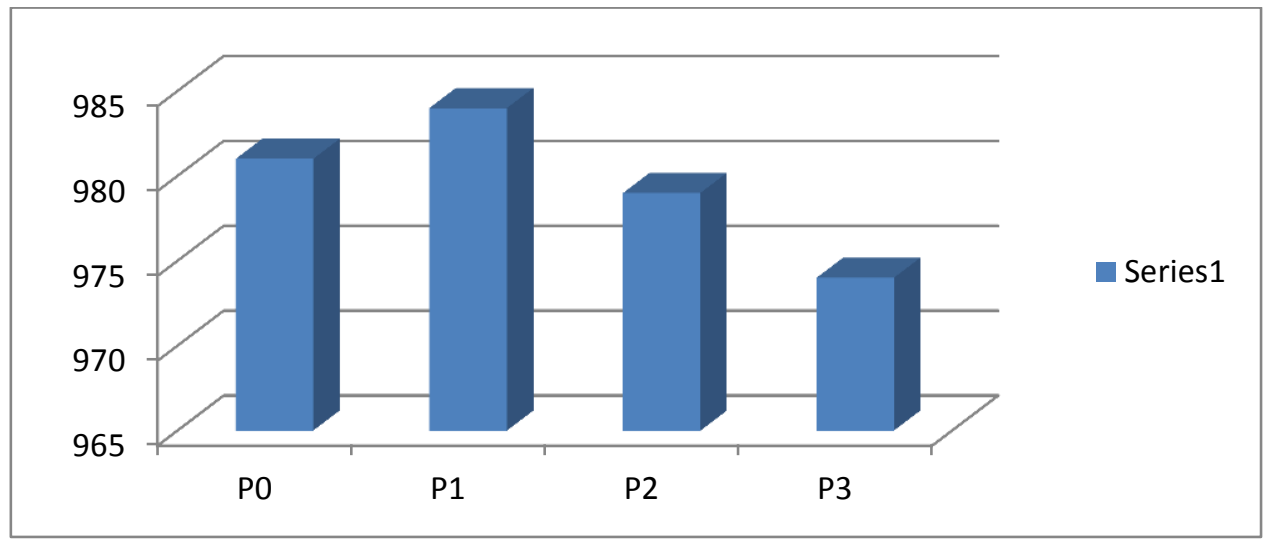

Gambar 2. Diagram Pertambahan Bobot Badan Komulatif Ayam Penelitian

\section{Konversi Ransum}

Konversi ransum adalah
Data konversi ransum ayam penelitian disampaiakan pada tabel 5 sebagai berikut

perbandingan antara konsumsi ransum dan pertambahan bobot badan seekor ternak.

Tabel 5. Konversi Ransum Ayam Penelitian

\begin{tabular}{|c|c|c|c|c|c|}
\hline \multirow{2}{*}{ PERLAKUAN } & \multicolumn{3}{|c|}{ ULANGAN } & \multirow{2}{*}{ TOTAL } & \multirow{2}{*}{ RATAAN } \\
\hline & 1 & 2 & 3 & & \\
\hline $\mathrm{P} 0$ & 1,56 & 1,59 & 1,44 & 4,58 & 1,53 \\
\hline $\mathrm{P} 1$ & 1,37 & 1,58 & 1,61 & 4,57 & 1,52 \\
\hline $\mathrm{P} 2$ & 1,49 & 1,57 & 1,33 & 4,39 & 1,46 \\
\hline P3 & 1,35 & 1,42 & 1,59 & 4,36 & 1,45 \\
\hline
\end{tabular}

Sumber : Data primer diolah, 2016

Hasil analisis sidik ragam (lampiran 4.3) mennjukkan bahwa pemberian perlakuan tidak berpengaruh nyata $(\mathrm{P}>0,05)$ terhadap konversi ransum, artinya pemberian tepung bawang putih yang dilarutkan dalam air minum tidak memberikan efek nyata 
terhadap penurunan konversi ransum. Namun secara numerik rataan konversi ransum ayam penelitian menurun seiring dengan meningkatnya taraf pemberian tepung bawang putih. Hal ini sesuai dengan data konsumsi ransum yang juga menurun seiring dengan meningkatnya taraf pemberian tepung bawang putih, disisi lain pertambahan bobot badan yang merupakan faktor pembagi dalam penghitungan konversi tidak selalu menurun seiring dengan meningkatnya taraf pemberian tepung bawang putih, dimana pertambahan bobot badan tertinggi pada kelompok ayam yang diberi perlakuan P1. Dibandingkan dengan hasil penelitian Zulbardi dan Bintang (2007) yang melaporkan bahwa pemberian tepung bawang putih $0,02 \%$ pada ayam broiler menghasilkan konversi pakan 1,81 maka konversi ransum pada setiap perlakuan pada penelitian ini lebih kecil. Ilustrasi mengenai rataan konversi ransum ayam penelitian untuk masing-masing perlakuan dapat dilihat pada gambar 3 sebagai berikut

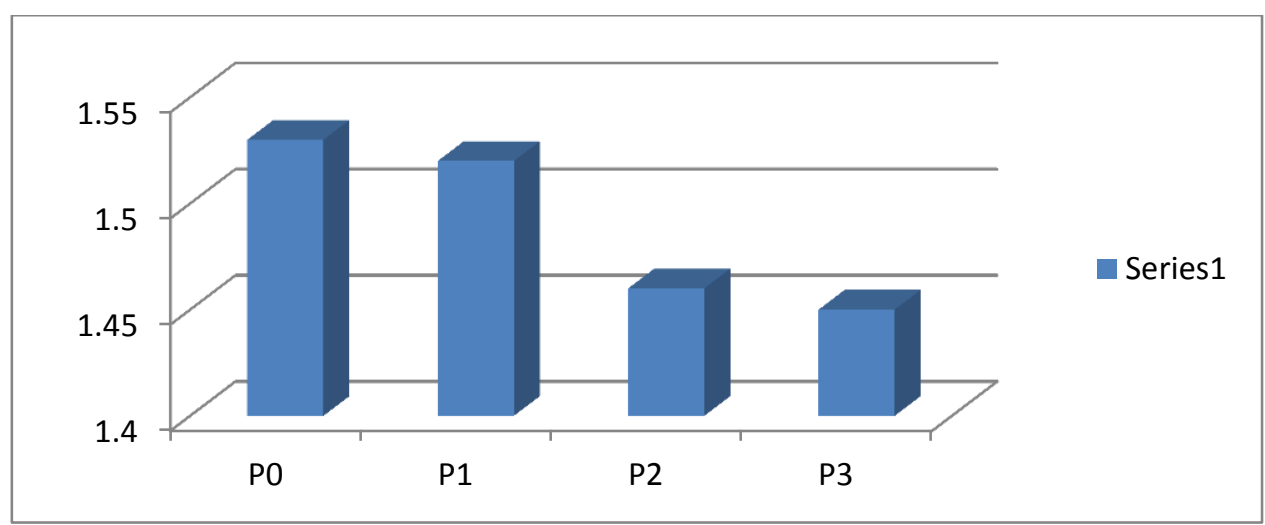

Gambar 3. Diagram Konversi Ransum Ayam Penelitian

\section{KESIMPULAN DAN SARAN}

Kesimpulan

Berdasarkan hasil penelitian dapat disimpulkan sebagai berikut :

1. Pemberian tepung bawang putih yang dilarutkan dalam air minum tidak memberikan efek nyata $(\mathrm{P}>0,05)$ terhadap peningkatan performans produksi ayam pedaging 4 minggu ( 28 hari).
2. Secara numerik semakin tinggi taraf pemberian tepung bawang putih, semakin rendah konsumsi maupun konversi ransumnya.

3. Secara pertambahan bobot badan tertinggi pada kelompok ayam yang diberi perlakuan P1 (yang diberi tepung bawang putih $5 \mathrm{gr} /$ liter) dan terendah pada kelompok ayam yang diberi 
perlakuan P3 (yang diberi tepung bawang putih $15 \mathrm{gr} /$ liter).

Saran
Perlu dilakukan penelitian dengan aspek yang sama dengan taraf yang lebih kecil $0,05 \%$ serta dengan aplikasi yang lebih bervariasi.

\section{DAFTAR PUSTAKA}

Anonimus, 1994. Taksonomi dan Kandungan Bawang Putih

http://excellent-smufy.blogspot.com/1994/06 taksonomi-dan-kandungan-bawangputih. html. Diakses 10 Jani 2016.

Anonimous, 2007. Kandungan dan Khasiat Bawan Putih.

http://www.kamusilmiah.com/kesehatan/kandungan-danKhasiat bawang putih/. Diakses 10 Juni 2016.

Anonimous, 2008. Alium ativum L. ( Bawang Putih )

http://obtrando.wordpress.com/buk-aliumativum-I-bawang putih/html Diakses 10 Juni 2016

Anonimous, 2009. Teknis Pemeliharaan Ayam Pedaging.

http://go-rganik.blogspot.com/2008/08teknispemeliharaan-ayam pedaging $/ \mathrm{html}$. Diakses tanggal 24 Juni 2016.

Anggorodi,R.1994. .Ilmu Makanan Ternak Umum. Penerbit Gramedia. Jakarta.

Guil, B.A and K.W. Wasburn, 1978. Cage and Feed Rhough For Individual Broiler Feed ConsumtionExperiments. Poultry Science

Hardjosubroto, W.dan J.M. Austiti. 1994. Buku Pintar Peternakan. PT Gramedia Widiasarana Indinesia Yogyakarta

Kartadisastra, H.R. 1994. Pengelolaan Pakan Ayam. Kanisius, Yogyakarta.

Koentjoko,1978. Ilmu Pengetahuan Bahab Pakan dan Formilasi Ransum.Fakultas Peternakan Unifersitas Bara Wijaya Malang

Lesson, S .2001. Nutrtion and Quality of Broiler Carcas. Departemen of animal and poultry Science. University of Guelph. California.

Maryam,R.,Y.Sani,S.Juariah, .Firmansyah, dan Miharja. 2003. Efektivitas Ekstrak Bawang Putih (Allium Sativum Linn). Dalam Penanggulangan Aflatoksikosis Pada Ayam Petelur. Jurnal ilmu ternak dan veteriner Vol. 8 No. 4 Th 2003 : 239 - 246.

Murtidjo, B. A., 1992. Pedoman Beternak Ayam Broiler. Kanisius. Yogyakarta.

Nesheim, M.C., R.E. Austic and L.E Card et al,. 1979. Poultry Production. $12^{\text {th. }}$ Fd. Lea and Febriger. Philadelphia.

NRC, 1994. National Research Council. National. Nutrient Requirements of Poultry. Ninth Revised Edition Nutrient of Academic Science. Washington, DC.

North,M.O. 1992. Comercial Chisken production Manual.5 th Edition. Avi Publishing Co Inc. Westport. Connecticut.

Rasyaf, M. 2000. Panduan Beternak Ayam Pedaging. Penerbit Penebar Swadaya, Jakarta.

Rizal, Y. 2006. Ilmu Nutrisi unggas. Andalas University Press. Padang

Santoso, B. 1989. Bawang Putih. Kanisius. Yogyakarta

Scott, M.L,.M.. Nesheim and R.J. Young. et al., 1992. Nutrition of The Chicken. Fifth Edition. Scott M. L. and Associates. New York.

Siregar, A.P.,M. et al., 1980. Teknik Beternak Ayam Pedaging di Indonesia. Mergie Group, Jakarta.

Steel R. G. D. dan Torrie, J. H. 1989. Prinsip dan Prosedur Statistika Suatu Pendekatan Biometrika. Penerbit PT Gramedia Pustaka Utama, Jakarta. 
Suharsono, 1976. Respon Ayam Pedaging Terhadap Berbagai Kondisi Lingkungan. Universitas Pajajaran, Bandung.

Suprijatna, E., U. Atmomarsono., dan R. Kartasudjana. 2005. Ilmu dasar Ternak Unggas. Penebar Swadaya. Jakarta

Sutama,S.I.N., dan Sri .A.Lindawati. Pengaruh Suplementasi Bawang Putih (Allium sativum L) terhadap Produksi dan Kandungan Kolestrol Telur Ayam Hysex Brown. Animal Production Vol. 10 No. 3 Th 2005 : 168 -173.

Tarmudji, 2006. Manfaat Gel lidah Buaya Untuk Unggas. http://www.Poultry.go.id. Diakses 6 Maret 2010

Tampubolon, O.T. 1981. Tumbuhan Obat Bagi Pecinta Alam. Jakarta: Bharata Karya Aksara.
Wahyu, J., 2004. Ilmu Nutrisi Ternak Unggas. Gadjah Mada University Press. Yogyakarta.

Yamin dan Mozin,M 2002. Pengaruh Tingkat Protein Pakan terhadap Konsumsi, Pertambahan Bobot Badan dan IOFC Ayam Buras Umur 0-8 Minggu. Jurnal Agroland Vol. 9 No. 3 September 2002.

Zulbardi.M, dan I.A.K. Bintang, 2007. Mencapai Bobot Badan Siap Pasar Melalui Penggunaan Bawang Putih (Allium sativum L) pada Ransum Komersial untuk Ayam Broiler. Jurnal Indonesia Tropic Animal Agriculture Vol. 32 No. 3 Th 2007: 167 - 172 
